\title{
Penerapan Model Pembelajaran Numbered Head Together (NHT) untuk Meningkatkan Aktivitas dan Hasil Belajar Siswa Kelas II pada Pembelajaran Tematik SDN Parang 4 Kecamatan Banyakan Kabupaten Kediri
}

\author{
Diterima: \\ 15 Januari 2021 \\ Revisi: \\ 25 Januari 2021 \\ Terbit:
}

1 Februari 2021

\author{
Dina Fatkhul Janah \\ Sekolah Dasar Negeri Parang 4 Kabupaten Kediri \\ Kediri, Indonesia \\ E-mail: dinaputriharianto@gmail.com
}

\begin{abstract}
Abstrak- Berdasarkan hasil data di SDN Parang 4, ditemukan fakta bahwa 62,5\% siswa kelas 2 SDN Parang 4 mendapatkan nilai di bawah KKM yaitu dibawah nilai 70.00. Dalam pembelajaran, guru hanya cenderung berceramah yang monoton dan guru tidak menggunakan model pembelajaran saat melaksanakan pembelajaran di dalam kelas, dan siswa masih berperan pasif di dalamnya. Mengingat latar belakang siswa kelas 2 di SDN Parang 4 maka dirumuskan sebuah solusi yaitu menggunakan model pembelajaran Numbered Head Together (NHT) untuk meningkatkan aktivitas dan hasil belajar siswa. Pendekatan yang digunakan adalah penelitian kualitatif dengan desain Penelitian Tindakan Kelas (PTK) dengan tahapan yaitu 1) perencanaan, 2) pelaksanaan, 3) pengamatan, 4) refleksi. Penelitian ini dberlangsung selama 2 siklus, tiap siklus 2 pertemuan dengan materi pembelajaran tematik. Berdasarkan hasil penelitian, dapat disimpulkan bahwa model pembelajaran Numbered Head Together (NHT) dapat meningkatkan aktivitas dan hasil belajar siswa pada tematik.
\end{abstract}

Kata Kunci- Numbered Head Together (NHT), aktivitas belajar, hasil belajar

Abstract - Based on the results of the data at SDN Parang 4, it was found that $62.5 \%$ of grade 2 students at SDN Parang 4 got a score below the KKM, which was under the value of 70.00. In learning, teachers only tend to give monotonous lectures and teachers do not use learning models when carrying out learning in the classroom, and students still play a passive role in it. Considering the background of grade 2 students at SDN Parang 4, a solution was formulated, namely using the Numbered Head Together (NHT) learning model to improve student activities and learning outcomes. The approach used is qualitative research with Classroom Action Research (CAR) design with stages: 1) planning, 2) implementation, 3) observation, 4) reflection. This research was conducted for 2 cycles, each cycle 2 meetings with thematic learning materials. Based on the results of the study, it can be concluded that the Numbered Head Together (NHT) learning model can increase students' activities and learning outcomes on thematics.

Keywords - Numbered Head Together (NHT), learning activities, learning outcomes 


\section{PENDAHULUAN}

Tugas pokok dan fungsi seorang guru adalah melaksanakan kegiatan pembelajaran. Salah satu faktor yang mempengaruhi keberhasilan proses pembelajaran antara lain, penyampaian materi pembelajaran yang dilakukan oleh guru. Dalam pembelajaran di kelas guru seharusnya dapat memilih model pembelajaran yang tepat sesuai dengan pokok bahasan dan keadaan siswa, karena guru merupakan faktor penting yang besar pengaruhnya, bahkan sangat menentukan berhasil tidaknya peserta didik dalam belajar (Dimyati dkk. 2006). Mengingat banyaknya model pembelajaran yang dapat digunakan guru dalam pembelajaran di kelas, maka hal tersebut telah memberikan alternatif pada guru dalam menggunakan model pembelajaran. Model pembelajaran yang dapat dikembangkan untuk membangun pengetahuan siswa salah satunya dengan model pembelajaran Numbered Head Together (NHT).

Model pembelajaran Numbered Head Together (NHT) adalah model pembelajaran yang mampu membuat siswa menerima berbagai pendapat yang disampaikan oleh orang atau kelompok lain, kemudian menganalisisnya bersama, sehingga memunculkan pendapat yang paling ideal. Inilah sebenarnya esensi dari perbedaan pendapat. Selanjutnya, guru memberikan kesimpulan terhadap jalannya pembahasan materi. Model pembelajaran Numbered Head Together (NHT) menghadirkan terjadinya interaksi antara siswa melalui diskusi atau siswa secara bersama dalam menyelesaikan masalah yang dihadapi. Hal ini berarti bahwa hasil belajar bisa diperoleh dengan sharing antar teman, siswa pandai maupun siswa lemah sama-sama memperoleh manfaat melalui aktifitas belajar kooperatif. Dengan demikian pada model pembelajaran Numbered Head Together (NHT) ini pembelajaran dikemas dalam berdiskusi kelompok yang anggotanya heterogen, dengan jumlah yang bervariasi (Dwi Febriany and Ivada 2013).

Berdasarkan hasil data di SDN Parang 4, ditemukan fakta bahwa 62,5 \% siswa kelas 2 SDN Parang 4 mendapatkan nilai di bawah KKM. Dari jumlah keseluruhan siswa yang mampu mencapai KKM hanya 4 siswa, sedangkan yang mendapatkan nilai bawah KKM ada 8 siswa. Hal ini berarti nilai rata-rata yang dicapai siswa kelas 2 SDN Parang 4 di bawah KKM. Selain hal tersebut dalam pembelajaran sehari-hari guru hanya menyampaikan materi secara konvensional saja. Guru hanya cenderung berceramah yang monoton dan guru tidak menggunakan metode saat melaksanakan pembelajaran di dalam kelas, sehingga saat siswa diberi kesempatan untuk bertanya, sedikit sekali diantara mereka yang mengajukan pertanyaan karena pada saat guru berceramah siswa tidak memperhatikan materi yang disampaikan oleh guru. Aktivitas siswa juga sangat rendah, karena ketika guru memberikan latihan soal kepada siswa, ada beberapa siswa yang hanya duduk dan tampak tidak bersemangat dalam belajar. 
PTK, Vol.2 No.1 2021

ISSN: 2747-1977 (Print) / 2747-1969 (Online)

DOI: https://doi.org/10.53624/ptk.v2i1.55

Ketika hasil latihan soal dikumpulkan dan dikoreksi oleh guru ternyata banyak siswa yang kesulitan dalam mengerjakan soal latihan tersebut sehingga nilainya rendah.

Berdasarkan permasalahan diatas, penulis memiliki inovasi dengan menggunakan model pembelajaran Numbered Head Together (NHT). Numbered Head Together (NHT) adalah suatu cara untuk membuat variasi suasana pola diskusi kelas. Langkah-langkah model pembelajaran Numbered Head Together (NHT) adalah sebagai berikut (Novamizanti and Efri 2019): (1) siswa dibagi dalam kelompok dan setiap siswa dalam kelompok tersebut mendapatkan nomor kelompok. (2) guru memberikan tugas yang berkaian dengan materi pelajaran yang akan disampaikan dan masing-masing kelompok mengerjakannya bersama kelompok. (3) setiap kelompok mendiskusikan jawaban yang benar dan memastikan setiap anggota kelompok dapat mengerjakannya atau mengetahui jawaban yang mewakili dari kelompok tersebut. (4) untuk membahas hasil dari setiap kelompok tersebut, guru memanggil nomor kelompok tertentu untuk membahas jawaban mereka, kemudian memanggil nomor kelompok yang lain untuk memberi tanggapan atas jawaban dari kelompok yang mempresentasikan jawabannya. (5) Begitu seterusnya, hingga semua kelompok mendapatkan kesempatan untuk mempresentasikan hasil jawaban kelompok mereka dan kelompok yang lain menanggapinya dengan aktif dan interaktif. (6) terakhir, guru memberikan kesimpulan terhadap jalannya pembahasan dan pembelajaran tersebut.

Dengan demikian diharapkan dengan penerapan model pembelajaran Numbered Head Together (NHT) mampu mengatasi permasalahan rendahnya aktivitas dan hasil belajar tematik siswa kelas 2 SDN Parang 4 Kecamatan Banyakan Kabupaten Kediri. Berangkat dari hal-hal tersebut, peneliti tertarik untuk mengkaji Penerapan Model Pembelajaran Numbered Head Together (NHT) untuk Meningkatkan Aktivitas dan Hasil Belajar Siswa Kelas II pada Pembelajaran Tematik SDN Parang 4 Kecamatan Banyakan Kabupaten Kediri .

\section{METODE}

Jenis penelitian yang digunakan adalah penelitian tindakan kelas (PTK), dengan tahapan yaitu 1) perencanaan, 2) pelaksanaan, 3) pengamatan, 4) refleksi. Konsep penelitian ini mengacu pada model PTK Kemmis dan MC. Taggart (Akbar 2010). Dalam penelitian ini peneliti sebagai instrumen utama mengandung arti sebagai pengumpul dan pengolah data. Peneliti sebagai perencana tindakan maksudnya adalah peneliti yang membuat rancangan pembelajaran selama berlangsungnya penelitian. Kemudian peneliti melaksanakan pembelajaran di kelas sebagai guru kelas 2 SDN Parang 4 Kecamatan Banyakan Kabupaten Kediri. 
Subjek yang diteliti pada penelitian ini adalah siswa kelas 2 pada semester genap tahun ajaran 2019/2020 di SDN Parang 4 Kecamatan Banyakan Kabupaten Kediri dengan jumlah siswa sebanyak 12 siswa, yang terdiri dari 4 siswa laki-laki dan 8 siswa perempuan. Waktu penelitian ini dilaksanakan mulai tanggal 13 April 2020 sampai tanggal 13 Mei 2020 semester genap tahun pelajaran 2019/2020. Data yang di analisis dalam penelitian ini adalah sebagai berikut:

a. Aktivitas belajar siswa selama proses pembelajaran.

Untuk mengetahui tingkat aktivitas belajar siswa secara individu maka dipergunakan rumus sebagai berikut.

$\mathrm{NP}=\frac{n}{n m} \times 100 \%$

Keterangan:

$\mathrm{NP}=$ Nilai proses aktivitas siswa

$\mathrm{N}=$ Jumlah nilai yang diperoleh siswa

$\mathrm{Nm} \quad=$ Jumlah nilai maksimal semua aspek

Dalam menentukan tingkat kategori aktivitas belajar siswa dari hasil observasi, peneliti membagi dalam 5 kategori. Adapun kriteria aktivitas belajar siswa tersebut adalah sebagai berikut.

Tabel 1. Kriteria Aktivitas Belajar Siswa

\begin{tabular}{cc}
\hline Rentan Skor & Predikat \\
\hline $\mathbf{8 5 - 1 0 0}$ & Sangat Baik (A) \\
$\mathbf{7 0 - 8 4}$ & Baik (B) \\
$\mathbf{5 5 - 6 9}$ & Cukup (C) \\
$\mathbf{4 0 - 5 4}$ & Kurang (D) \\
$<40$ & Sangat Kurang $€$ \\
\hline
\end{tabular}

(Dwitagama, 2010)

Selain itu, untuk mengetahui peningkatan aktivitas siswa dengan cara membandingkan nilai persentase tiap siklus dengan terlebih dahulu mencari nilai rata-rata persentase aktivitas siswa menggunakan rumus.

$\mathrm{X}=\frac{\Sigma X}{\Sigma N}$

Keterangan :

$\mathrm{X}=$ Nilai rata-rata aktivitas siswa

$\Sigma \mathrm{X}=$ Jumlah nilai keseluruhan yang diperoleh siswa di kelas

$\Sigma \mathrm{N} \quad=$ Jumlah siswa keseluruhan 
PTK, Vol.2 No.1 2021

ISSN: 2747-1977 (Print) / 2747-1969 (Online)

DOI: https://doi.org/10.53624/ptk.v2i1.55

b. Hasil Belajar Siswa

Untuk mengetahui Ketuntasan Hasil Belajar Individu menggunakan rumus sebagai berkut.

$\mathrm{Hi}=\frac{n}{N} \times 100$

Keterangan:

$\mathrm{Hi}=$ skor pencapaian hasil belajar

$\mathrm{n}=$ jumlah skor hasil belajar yang diperoleh

$\mathrm{N}=$ jumlah skor maksimal hasil belajar

Dalam menentukan ketuntasan hasil belajar secara klasikal menggunakan rumus sebagai berikut:

$$
\mathrm{KBK}=\Sigma \frac{\text { siswa yang tuntas }}{\text { Jumlah seluruh siswa }} \times 100 \%
$$

Keterangan:

KBK = Ketuntasan belajar klasikal

Kriteria hasil belajar siswa, ditentukan berdasarkan tabel dibawah ini:

Tabel 2. Kriteria Hasil Belajar Siswa

\begin{tabular}{cc}
\hline Rentan Skor & Predikat \\
$\mathbf{8 5 - 1 0 0}$ & Sangat Baik (A) \\
$\mathbf{7 0 - 8 4}$ & Baik (B) \\
$\mathbf{5 5 - 6 9}$ & Cukup (C) \\
$\mathbf{4 0 - 5 4}$ & Kurang (D) \\
$<\mathbf{4 0}$ & Sangat Kurang $€$ \\
\hline
\end{tabular}

(Dwitagama, 2010)

\section{HASIL DAN PEMBAHASAN}

A. Analisis Aktivitas Belajar Siswa

Analisis aktivitas belajar siswa skor rata-rata aktivitas belajar siswa secara klasikal menunjukkan peningkatan yang cukup baik. Skor aktivitas belajar siswa secara klasikal pada siklus I berada pada kriteria cukup dengan skor 67,25. Pembelajaran dilanjutkan pada siklus II untuk meningkatkan aktivitas belajar siswa. Pada siklus II skor aktivitas belajar siswa secara klasikal meningkat menjadi kriteria baik sebesar 80,55. Peningkatan motivasi belajar siswa pada pembelajaran tema 8 , sub tema 1 , pembelajaran 1 dengan model pembelajaran Numbered Head Together (NHT) mulai dari siklus I hingga siklus II dapat diamati pada tabel 3. 
ISSN: 2747-1977 (Print) / 2747-1969 (Online)

DOI: https://doi.org/10.53624/ptk.v2i1.55

Tabel 3. Gambaran Peningkatan Aktivitas Belajar Siswa

\begin{tabular}{|c|c|c|c|c|c|c|c|c|c|}
\hline \multirow[b]{2}{*}{ No. } & \multirow{2}{*}{$\begin{array}{c}\text { Nama } \\
\text { (Inisial) }\end{array}$} & \multicolumn{7}{|c|}{ Nilai (\%) } & \multirow[b]{2}{*}{ Keterangan } \\
\hline & & \multicolumn{3}{|c|}{ Siklus I } & & \multicolumn{2}{|c|}{ Siklus II } & $\begin{array}{c}\text { Rata- } \\
\text { rata }\end{array}$ & \\
\hline 1. & AK & 52,86 & 61,9 & 71,42 & 66,66 & 85,71 & 76,19 & 80,95 & Meningkat \\
\hline 4. & $\mathrm{AF}$ & 57,14 & 57,14 & 61,9 & 59,52 & 76,19 & 85,71 & 80,95 & Meningkat \\
\hline 5. & $\mathrm{AA}$ & 61,9 & 71,42 & 71,42 & 71,42 & 85,71 & 90,48 & 88,95 & Meningkat \\
\hline 6. & ED & 57,14 & 61,9 & 61,90 & 61,90 & 80,95 & 80,95 & 80,95 & Meningkat \\
\hline 7. & $\mathrm{GE}$ & 57,14 & 61,9 & 71,42 & 66,66 & 76,19 & 85,71 & 80,95 & Meningkat \\
\hline 11. & WD & 61,9 & 61,9 & 76,19 & 69,04 & 80,95 & 85,71 & 83,33 & Meningkat \\
\hline \multirow[t]{2}{*}{12.} & WA & 57,14 & 61,90 & 71,42 & 66,66 & 71,43 & 76,19 & 73,81 & Meningkat \\
\hline & Rata-rata & 58,00 & 65,90 & 68,64 & 67,25 & 77,80 & 83,54 & 80,55 & Meningkat \\
\hline
\end{tabular}

Berdasarkan tabel 3, terjadi peningkatan nilai rata-rata aktivitas siswa yang diperoleh pada masing-masing siklus selama mengikuti pembelajaran tema 8 , subtema 1 , pembelajarn 1 dengan penerapan model pembelajaran Numbered Head Together (NHT). Pada pra-tindakan aktivitas belajar siswa mendapatkan nilai rata-rata 58,00 pada siklus I aktivitas belajar siswa meningkat nilai rata-ratanya menjadi 67, 25 atau sekitar 15,94\% kemudian meningkat di siklus II nilai rata-ratanya menjadi 80,55 atau meningkat sekitar 19,77\%.

\section{B. Analisis hasil belajar siswa}

Hasil belajar dalam penelitian ini yaitu diperoleh dari pemberian tes akhir siklus yang dilaksanakan pada pertemuan kedua dalam siklus I dan siklus II. Berdasarkan analisis hasil tes siklus I, dari jumlah 12 orang siswa kelas 2 terdapat 5 orang siswa yang mendapat skor $<70$. Hasil ini dapat dikatakan bahwa siswa tersebut kurang memahami dan maemperhatikan materi yang dipelajari ketika guru menjelaskan dalam proses belajar. Pada pelaksanaan tes siklus I ini nilai tertinggi yang dicapai siswa adalah 77,5 dan nilai terendah 62,5. Pada analisis hasil tes siklus II, dari jumlah 12 orang siswa, terdapat 1 orang siswa saja yang mencapai skor $<70$, selebihnya mencapai nilai $\geq 70$. Soal tes akhir siklus 2 terdiri dari 10 soal pilihan ganda. Nilai tertinggi yang dicapai siswa adalah 87,5 dan nilai terendahnya 65. Berdasarkan uraian tersebut dapat dikatakan bahwa pembelajaran pada siklus II lebih berhasil dibandingkan dengan pembelajaran siklus I. Berikut ini perbandingan hasil tes pada siklus I dan siklus II pada tabel 4. 
PTK, Vol.2 No.1 2021

ISSN: 2747-1977 (Print) / 2747-1969 (Online)

DOI: https://doi.org/10.53624/ptk.v2i1.55

Tabel 4. Perbandingan Hasil Tes pada Siklus I dan Siklus II

\begin{tabular}{|c|c|c|c|c|c|c|c|c|c|}
\hline \multirow[b]{2}{*}{ No } & \multirow{2}{*}{$\begin{array}{c}\text { Nama } \\
\text { (Inisial) }\end{array}$} & \multirow[t]{2}{*}{ Pra-tindakan } & \multicolumn{2}{|c|}{ Siklus I } & \multicolumn{4}{|c|}{ Siklus II } & \multirow[t]{2}{*}{ Keterangan } \\
\hline & & & P1 & $\mathbf{P 2}$ & $\begin{array}{c}\text { Rata- } \\
\text { rata }\end{array}$ & P1 & $\mathbf{P 2}$ & $\begin{array}{c}\text { Rata- } \\
\text { rata }\end{array}$ & \\
\hline 1. & $\mathrm{AK}$ & 70 & 75 & 80 & 77,5 & 85 & 90 & $\mathbf{8 7 , 5}$ & Meningkat \\
\hline 2. & $\mathrm{AR}$ & 50 & 60 & 65 & 62,5 & 65 & 65 & 65 & Meningkat \\
\hline 3. & AW & 70 & 75 & 75 & 75 & 80 & 90 & 85 & Meningkat \\
\hline 4. & $\mathrm{AF}$ & 60 & 65 & 70 & 67,5 & 65 & 80 & 77,5 & Meningkat \\
\hline 5. & $\mathrm{AA}$ & 55 & 60 & 65 & 62,5 & 75 & 80 & 77,5 & Meningkat \\
\hline 6. & ED & 55 & 65 & 70 & 67,5 & 80 & 75 & 75 & Meningkat \\
\hline 7. & $\mathrm{GE}$ & 65 & 65 & 65 & 65 & 60 & 80 & 75 & Meningkat \\
\hline 8. & GF & 60 & 65 & 65 & 65 & 85 & 90 & 87,5 & Meningkat \\
\hline 9. & MS & 65 & 60 & 65 & 62,5 & 80 & 85 & 82,5 & Meningkat \\
\hline 10. & SI & 70 & 75 & 80 & 77,5 & 85 & 90 & 87,5 & Meningkat \\
\hline 11. & WD & 60 & 70 & 70 & 70 & 75 & 80 & 77,5 & Meningkat \\
\hline 12. & WA & 70 & 70 & 75 & 72,5 & 80 & 85 & 82,5 & Meningkat \\
\hline \multicolumn{2}{|c|}{ Rata-rata } & 62,5 & 68,33 & 70,41 & 69,58 & 76,25 & 82,50 & 80,0 & Meningkat \\
\hline \multicolumn{2}{|c|}{$\begin{array}{c}\text { Ketuntasan } \\
\text { secara Klasikal }\end{array}$} & $33,3 \%$ & $41,6 \%$ & $58,3 \%$ & $41,6 \%$ & $75 \%$ & $91,6 \%$ & $91,6 \%$ & Meningkat \\
\hline
\end{tabular}

Berdasarkan tabel 4, diperoleh hasil peningkatan nilai rata-rata hasil belajar siswa dan nilai ketuntasan klasikal dari pra-tindakan dan setelah tindakan. Pada pra-tindakan, nilai rata-rata hasil belajar siswa sebesar 62,5 dengan ketuntasan secara klasikal 33,3\%. Setelah dilaksanakannya tindakan yaitu menerapkan model pembelajaran Numbered Head Together (NHT) pada pembelajaran tema 8, subtema 1, pembelajaran 1 nilai rata-rata hasil belajar siswa di siklus I meningkat menjadi 69,58 dengan rata-rata ketuntasan secara klasikal sebesar 41,6\%. Ketuntasan secara klasikal tersebut belum mencapai $75 \%$. Kemudian di siklus II yang merupakan perbaikan dari tindakan sebelumnya nilai rata-rata hasil belajar siswa meningkat lagi menjadi 80,0 dengan ketuntasan klasikal sebesar 91,6\%. Berikut ini perbandingan hasil tes pada siklus I dan siklus II pada gambar diagram.

\section{Pembahasan}

Metode pengumpulan data dalam penelitian ini menggunakan wawancara, observasi, dokumentasi, dan tes. Berdasarkan hasil analisis data diketahui aktivitas belajar siswa mengalami peningkatan sebesar 13,3. Pada siklus I rata-rata skor aktivitas belajar siswa secara klasikal sebesar 67,25 dan pada siklus II sebesar 80,55 sehingga mengalami peningkatan sebesar 13,3. Hasil ini semakin mempertegas hasil penelitian sebelumnya yang menyimpulkan bahwa penerapan model pembelajaran Numbered Head Together efektif meningkatkan aktivitas belajar siswa, khususnya motivasi siswa dalam mengikuti pembelajaran (Siswaya 2019). Selain itu, skor hasil belajar juga mengalami peningkatan dari siklus I ke siklus II. Skor hasil belajar siswa secara klasikal pada siklus I sebesar 69,58 dan pada siklus II sebesar 80,00 mengalami peningkatan sebesar 10,42. Hasil ini senada dengan penelitian sebelumnya yang menyimpulkan 
bahwa model pembelajaran Numbered Head Together efektif membantu siswa memahami materi-materi pelajaran sehingga hasil belajar siswa dapat mengalami peningkatan atau mencapai target pembelajaran (Kistian 2018).

\section{KESIMPULAN}

Berdasarkan hasil penelitian yang telah dilakukan, dapat ditarik kesimpulan bahwa penerapan model pembelajaran Numbered Head Together (NHT) dapat meningkatkan aktivitas belajar siswa dan hasil belajar siswa. Hal ini berdasarkan peningkatan skor rata-rata aktivitas belajar siswa pada siklus I dengan siklus II. Peningkatan siklus I menunjukkan bahwa aktivitas belajar siswa mengalami peningkatan dari siklus I sebesar 67,25 menjadi 80,55 pada siklus II. Jadi, peningkatan skor rata-rata aktivitas belajar siswa mengalami peningkatan sebesar 13,3. Hasil belajar siswa secara klasikal juga mengalami peningkatan dari tiap siklusnya yaitu pada siklus I mencapai 41,6\% dan siklus II meningkat menjadi 91,6\%. Pencapaian hasil belajar ini sudah melampui batas ketuntasan belajar secara klasikal yang telah ditetapkan yaitu $75 \%$ dan hasil belajar ini dapat dikatakan dalam kategori baik. Dengan demikian pembelajaran melalui penerapan model pembelajaran Numbered Head Together (NHT) dapat dikatakan berhasil.

\section{DAFTAR PUSTAKA}

Akbar, Sa'dun. 2010. Penelitian Tindakan Kelas, Filosofi, Metodologi. Yogyakarta: CV Citra Implementasi Media

Dimyati dkk. 2006. Belajar dan Pembelajaran. Jakarta: Rineka Cipta.

Dwitagama dkk. 2010. Mengenal Penelitian Tindakan Kelas. Jakarta: PT Indeks.

Dwi Febriany, Diny and Elvia Ivada. 2013. "Hal 1 s/d 11 Diny Dwi Febriany, Pengaruh Pembelajaran Kooperatif Tipe Numbered Heads Together (NHT) Untuk Meningkatkan Hasil Belajar Akuntansi." Jupe UNS 1(2).

Kistian, Agus. 2018. "Pengaruh Model Pembelajaran Numbered Head Together (NHT) Terhadap Hasil Belajar Matematika Siswa Di Kelas IV SDN 4 Banda Aceh." Genta Mulia: Jurnal Ilmiah Pendidikan 9(2).

Novamizanti, Ledya and Efri, Suhartono. 2019. Penerapan Model Pembelajaran Number Head Together (Nht) untuk Meningkatkan Keaktifan dan Hasil Belajar Matematika Diskrit. Bandung: Universitas Telkom.

Siswaya, Ida Bagus Widana. 2019. "Implementasi Model Pembelajaran Kooperatif Tipe Numbered Head Together (NHT) Untuk Meningkatkan Aktivitas Dan Hasil Belajar Teknik Dasar Lompat Jauh Gaya Jongkok Pada Siswa." Jurnal Imiah Pendidikan Dan Pembelajaran 3(1):16-23. 